\title{
Discovery of acetylene hydratase activity of the iron-sulphur protein IspH
}

\author{
Ingrid Span ${ }^{1, \star}$, Ke Wang $^{2, \star}$, Weixue Wang ${ }^{3}$, Yonghui Zhang ${ }^{2}$, Adelbert Bacher ${ }^{1}$, Wolfgang Eisenreich ${ }^{1}$, \\ Kai Li ${ }^{2}$, Charles Schulz ${ }^{4}$, Eric Oldfield ${ }^{2,3} \&$ Michael Groll ${ }^{1}$
}

The final step of the methylerythritol phosphate isoprenoid biosynthesis pathway is catalysed by the iron-sulphur enzyme $\mathrm{IspH}$, producing the universal precursors of terpenes: isopentenyl diphosphate and dimethylallyl diphosphate. Here we report an unforeseen reaction discovered during the investigation of the interaction of $\mathrm{IspH}$ with acetylene inhibitors by X-ray crystallography, Mößbauer, and nuclear magnetic resonance spectroscopy. In addition to its role as a $2 \mathrm{H}^{+} / 2 \mathrm{e}^{-}$reductase, IspH can hydrate acetylenes to aldehydes and ketones via anti-Markovnikov/Markovnikov addition. The reactions only occur with the oxidised protein and proceed via $\eta^{1}-0$-enolate intermediates. One of these is characterized crystallographically and contains a C4 ligand oxygen bound to the unique, fourth iron in the $4 \mathrm{Fe}-4 \mathrm{~S}$ cluster: this intermediate subsequently hydrolyzes to produce an aldehyde product. This unexpected side to $\mathrm{IspH}$ reactivity is of interest in the context of the mechanism of action of other acetylene hydratases, as well as in the design of antiinfectives targeting $\mathrm{IspH}$.

\footnotetext{
${ }^{1}$ Department of Chemistry, Center for Integrated Protein Science, Technische Universität München, Lichtenbergstrasse 4, 85747 Garching, Germany. 2 Department of Chemistry, 600 South Mathews Avenue, University of Illinois, Urbana, Illinois 61801, USA. ${ }^{3}$ Center for Biophysics and Computational Biology, 607 South Mathews Avenue, University of Illinois, Urbana, Illinois 61801, USA. ${ }^{4}$ Department of Physics, Knox College, 2 East South Street, Galesburg, Illinois 61401, USA. *These authors contributed equally to this work. Correspondence and requests for materials should be addressed to E.O. (email: eo@chad.scs.uiuc.edu) or to M.G. (email: michael.groll@mytum.de).
} 
$\mathrm{M}$ etalloproteins containing $\left[\mathrm{Fe}_{4} \mathrm{~S}_{4}\right]$ clusters carry out a broad series of reactions ${ }^{1,2}$. For example, aconitase ${ }^{3}$ catalyses the hydration of the alkene-containing species cis-aconitate to citrate and iso-citrate, whereas ferredoxins $s^{1,4}$ mediate electron transfer reactions. In isoprenoid biosynthesis, the protein $(E)-4$ hydroxy-3-methyl-but-2-enyl diphosphate (HMBPP, 1) reductase (IspH, Fig. 1a) performs a $2 \mathrm{H}^{+} / 2 \mathrm{e}^{-}$reduction and deoxygenation of $\mathbf{1}$, yielding isopentenyl diphosphate (2) and dimethylallyl diphosphate (3) (Fig. 1b) ${ }^{5-12}$. This reaction is of interest in the context of drug development, as IspH is essential for the growth of many pathogenic bacteria, as well as of malaria parasites ${ }^{13-15}$.

Here we report that, in addition to its role as a $2 \mathrm{H}^{+} / 2 \mathrm{e}^{-}$reductase in isoprenoid biosynthesis, IspH can catalyse a second class of reactions: the addition of water to acetylene groups to produce aldehyde and ketone products. These reactions are shown to occur via $\eta^{1}$-O-enolate intermediates, one of which is characterized by crystallography, with the ligand's oxygen at $\mathrm{C} 4$ being found to bind to the unique fourth iron of the $\left[\mathrm{Fe}_{4} \mathrm{~S}_{4}\right]$ cluster. This acetylene hydration is equivalent to the reaction catalysed by the $\mathrm{W}(\mathrm{IV})$-containing protein acetylene hydratase ${ }^{16}$, where enolate formation has recently been proposed on theoretical grounds to be part of the mechanism ${ }^{17}$.

\section{Results}

Mößbauer studies of acetylene inhibitors. We started with a Mößbauer spectroscopic investigation of the IspH inhibitors ${ }^{18}$ propynyl diphosphate (4), but-3-ynyl diphosphate (5), and pent-4ynyl diphosphate (6) bound to oxidised IspH from E. coli (Fig. 2). All compounds gave similar Mößbauer spectra (Fig. 3a-c) with quadrupole splittings $\left(\Delta \mathrm{E}_{\mathrm{Q}}\right)$ of $\sim 1.1 \mathrm{~mm} \mathrm{~s}^{-1}$ and isomer shifts $\left(\delta_{\mathrm{Fe}}\right)$ of $\sim 0.45 \mathrm{~mm} \mathrm{~s}^{-1}$. These values differ from those seen in ligand-free IspH (Fig. 3d) ${ }^{19}$. However, they are similar to those observed on addition of the HMBPP substrate (1) to the enzyme, where the quadrupole splitting of the fourth $\mathrm{Fe}$ changes from 1.91 to $1.00 \mathrm{~mm} \mathrm{~s}^{-1}$, and the isomer shifts decrease from 0.89 to $0.53 \mathrm{~mm} \mathrm{~s}^{-119}$. As noted by Seemann et al., based on previous work with aconitase and model systems, this indicates conversion from a $3 \mathrm{~S}, 3 \mathrm{~N} / \mathrm{O}$ (octahedral) to a $3 \mathrm{~S}, 1 \mathrm{O}$ (tetrahedral) coordination sphere of the iron ${ }^{19,20}$. The Mößbauer results of IspH in complex with 4-6 also suggest a 3S,1O coordination on inhibitor binding, as reported for the substrate 1 .

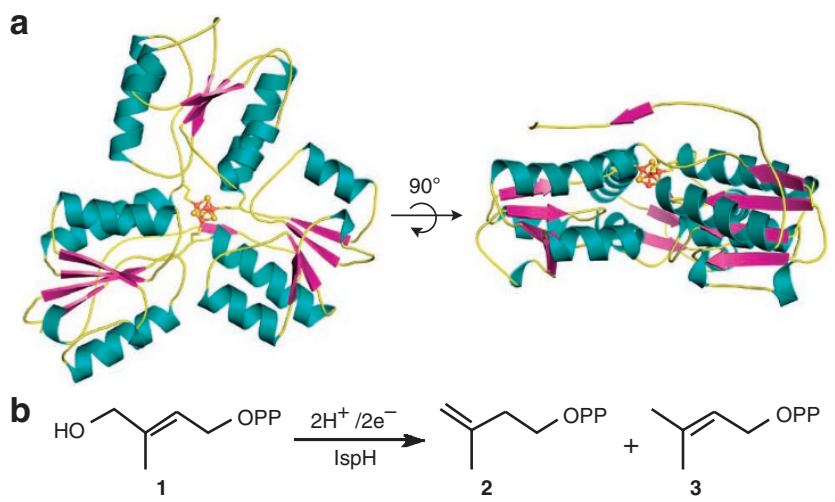

Figure 1 | Structure and enzymatic activity of IspH. (a) Top and side view of the overall crystal structure of IspH protein from Escherichia coli. The protein comprises three structurally similar domains with a $\left[\mathrm{Fe}_{4} \mathrm{~S}_{4}\right]$ cluster in the active site. The cluster is displayed as ball and stick model, whereas the protein is shown as cartoon. (b) Reaction of (E)-4-hydroxy3-methylbut-2-enyl diphosphate (1) to isopentenyl diphosphate (2) and dimethylallyl diphosphate (3) catalysed by the $2 \mathrm{H}^{+} / 2 \mathrm{e}^{-}$reductase $\mathrm{IspH}$ This conversion represents the final step in the non-mevalonate pathway leading to the universal precursors, $\mathbf{2}$ and $\mathbf{3}$, in isoprenoid biosynthesis.
Propynyl diphosphate (4) is not converted by IspH. Subsequently, we performed co-crystallization of compounds 4-6 bound to oxidised $\mathrm{IspH}$ and analysed the ligand-bound $\mathrm{X}$-ray structures obtained. As can be seen with 4 (Fig. 4a), the acetylene group is not bonded to the fourth $\mathrm{Fe}$ ( $\mathrm{Fe}-\mathrm{C}$ distances of 3.4-3.5 $\mathrm{A}$ ), rather, there is a water molecule (or, in principle, a hydroxide ion) bound to the $\left[\mathrm{Fe}_{4} \mathrm{~S}_{4}\right]$ cluster with a Fe-O bond length of $2.1 \AA$, essentially
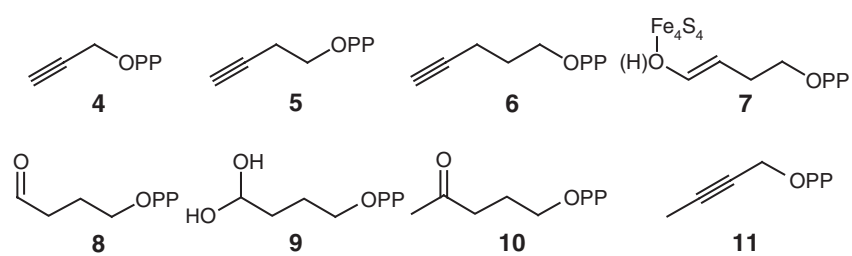<smiles>C=C=CCOP</smiles>

12

13

Figure 2 | Chemical structures of ligands binding to the active site of IspH. The acetylene diphosphates 4-6 were crystallized in complex with $\mathrm{IspH}$; the hydration products $\mathbf{7 - 1 0}$ have been observed in crystal structures or by NMR spectroscopy; compounds 11-13 bind to the catalytic centre of $\mathrm{IspH}$, but are not converted by the enzyme.
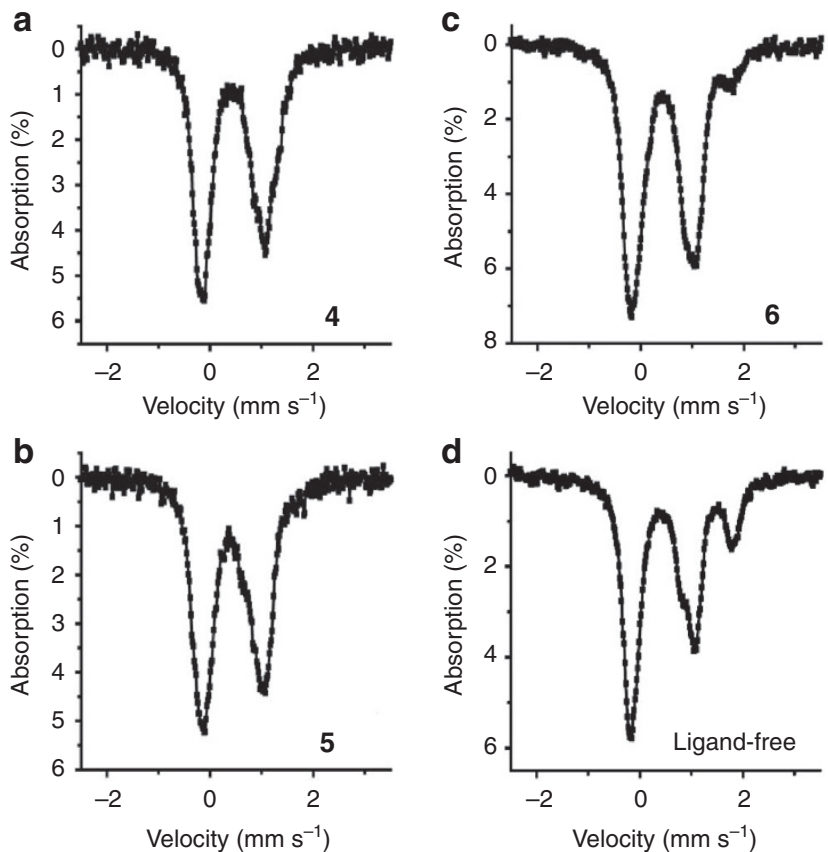

Figure $\left.3\right|^{57} \mathrm{Fe}$ Mößbauer data on IspH-acetylene interactions. Mößbauer spectra of oxidised $E$. coli IspH bound to: (a) propynyl diphosphate 4 (Component 1 (25\%) $\delta=0.52 \mathrm{~mm} \mathrm{~s}^{-1}, \Delta \mathrm{E}_{\mathrm{Q}}=1.54 \mathrm{~mm} \mathrm{~s}^{-1}$; Component $2(50 \%) \delta=0.45 \mathrm{~mm} \mathrm{~s}^{-1}, \Delta \mathrm{E}_{\mathrm{Q}}=1.20 \mathrm{~mm} \mathrm{~s}^{-1}$; Component 3 (25\%) $\delta=0.41 \mathrm{~mm} \mathrm{~s}^{-1}, \Delta \mathrm{E}_{\mathrm{Q}}=0.85 \mathrm{~mm} \mathrm{~s}^{-1}$ ); (b) but-3-ynyl diphosphate 5 (Component $1(50 \%) \delta=0.45 \mathrm{~mm} \mathrm{~s}^{-1}, \Delta \mathrm{E}_{\mathrm{Q}}=1.28 \mathrm{~mm} \mathrm{~s}^{-1}$; Component 2 (50\%) $\delta=0.39 \mathrm{~mm} \mathrm{~s}^{-1}, \Delta \mathrm{E}_{\mathrm{Q}}=0.89 \mathrm{~mm} \mathrm{~s}^{-1}$ ); (c) pent-4-ynyl diphosphate 6 (Component $1(50 \%) \delta=0.42 \mathrm{~mm} \mathrm{~s}^{-1}, \Delta \mathrm{E}_{\mathrm{Q}}=1.54 \mathrm{~mm} \mathrm{~s}^{-1}$; Component $\left.2(50 \%) \delta=0.45 \mathrm{~mm} \mathrm{~s}^{-1}, \Delta \mathrm{E}_{\mathrm{Q}}=1.20 \mathrm{~mm} \mathrm{~s}^{-1}\right) ;($ d) ligand-free IspH (Component $1(50 \%) \delta=0.43 \mathrm{~mm} \mathrm{~s}^{-1}, \Delta \mathrm{E}_{\mathrm{Q}}=1.28 \mathrm{~mm} \mathrm{~s}^{-1}$; Component $2(25 \%) \delta=0.38 \mathrm{~mm} \mathrm{~s}^{-1}, \Delta \mathrm{E}_{\mathrm{Q}}=0.86 \mathrm{~mm} \mathrm{~s}^{-1}$; Component $3(25 \%)$ $\left.\delta=0.82 \mathrm{mms}^{-1}, \Delta \mathrm{E}_{\mathrm{Q}}=1.98 \mathrm{~mm} \mathrm{~s}^{-1}\right)$. 
$\mathbf{a}$
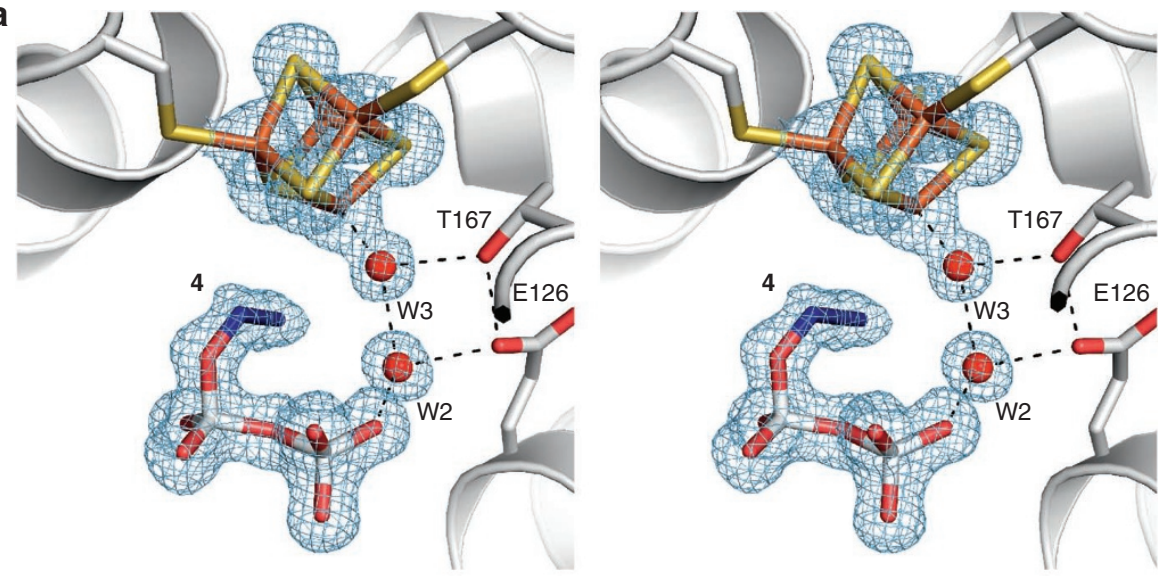

b
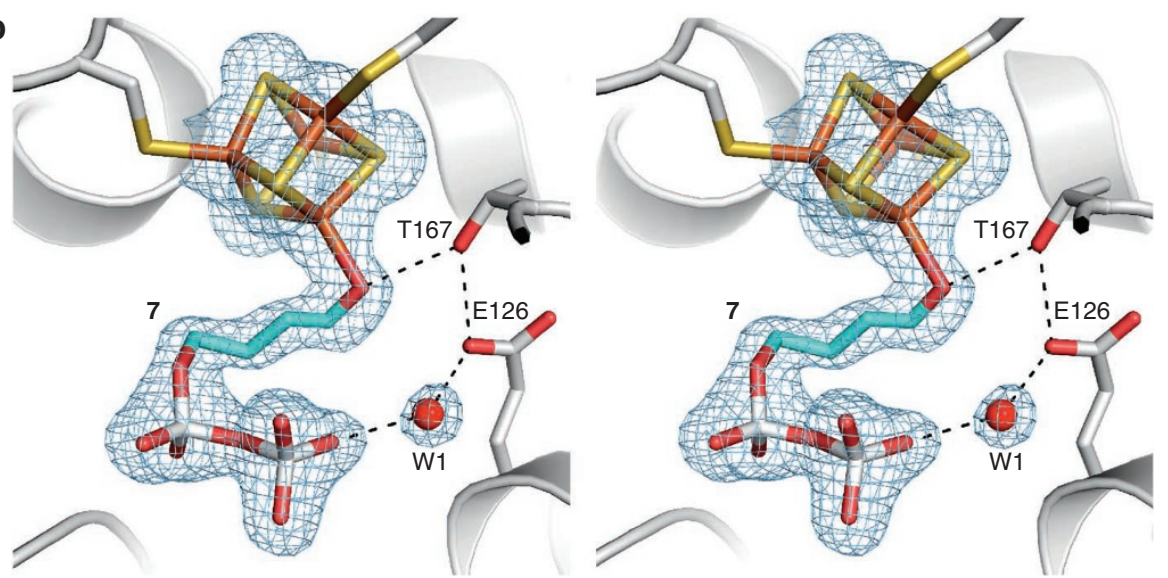

Figure 4 | Stereo presentation of the $\mathbf{E}$. coli IspH active site with ligands $\mathbf{4}$ and 7. Ligands, $\left[\mathrm{Fe}_{4} \mathrm{~S}_{4}\right]$ clusters and side chains of E126 as well as $\mathrm{T} 167$ are displayed as stick models. The protein backbone is presented as coil model (grey) and solvent molecules as spheres (red). A $2 F_{O^{-}} F_{C}$ omit electron density map (blue mesh, contoured at $1.4 \sigma$ ) is shown for the $\left[\mathrm{Fe}_{4} \mathrm{~S}_{4}\right]$ cluster, the ligand, and the solvent molecules in the first coordination sphere; dotted lines indicate coordination and hydrogen bonds. (a) Crystal structure of IspH bound to propynyl diphosphate (4). The diphosphate group of the ligand binds in the same orientation as observed for the substrate $\mathbf{1}$ (ref. 21), but no interaction between the alkyne group and the iron-sulphur cluster were observed. Two water molecules are located in the central cavity: W3 coordinates to the fourth site of the apical iron of the $\left[\mathrm{Fe}_{4} \mathrm{~S}_{4}\right]$ cluster and W2 is stabilized by $\mathrm{E} 126 \mathrm{O}^{\varepsilon}$ as well as the diphosphate group. (b) IspH active site with the $\eta^{1}$-enolate $\mathbf{7}$ and water molecule W1. IspH hydrates but-3-ynyl diphosphate (5) to the corresponding aldehyde $\mathbf{8}$.

the same as in the alkoxide complex formed by oxidised IspH and $\operatorname{HMBPP}(\mathbf{1})^{21}$. The crystal structure of IspH in complex with $\mathbf{4}$ gives an explanation of the ${ }^{57} \mathrm{Fe}$ Mößbauer results: the $\delta_{\mathrm{Fe}}$ and $\Delta \mathrm{E}_{\mathrm{Q}}$ values for $\mathbf{1}$ as well as $\mathbf{4}$ bound to IspH are essentially the same because both species contain a $\left[\mathrm{Fe}_{4} \mathrm{~S}_{4}\right]$ cluster with $3 \mathrm{~S}, 1 \mathrm{O}$ coordination to the apical Fe.

IspH converts but-3-ynyl diphosphate (5) to an aldehyde. Although the Mößbauer spectroscopic results with $\mathbf{4}$ and $\mathbf{5}$ are similar, the X-ray structure of IspH in complex with 5 reveals, surprisingly, an enolate complex (Fig. 4b). The diphosphate backbone of 5 binds to the same pocket as found with 1 and 4; however, the ligand has undergone a hydration reaction, forming 7 . The crystal structure determined at $2.0 \AA$ resolution clearly indicates formation of an $\eta^{1}$-O-enolate complex having an $\mathrm{Fe}-\mathrm{O}$ bond length of $2.0 \AA$ and, as with the IspH-substrate complex ${ }^{21}$, binding of 7 to IspH protects the $\left[\mathrm{Fe}_{4} \mathrm{~S}_{4}\right]$ cluster from $\mathrm{O}_{2}$, with IspH bound to $(E)$-4-hydroxybut-3-enyl diphosphate (7) being remarkably stable under aerobic conditions. Furthermore, this complex actually turns over, forming the aldehyde 4-oxobutyl diphosphate (8), as evidenced by the appearance of a ${ }^{1} \mathrm{H}$ NMR peak at 9.72 p.p.m. (Fig. 5a). In aqueous solution, such aldehydes exist in part as hydrates (gem-diols), and the J-couplings seen in Fig. 5a are consistent with the presence of both the free aldehyde as well as 4,4-dihydroxybutyl diphosphate (9), just as reported previously with 3-formyl-1-butyl diphosphate ${ }^{22}$. When 5 is added to IspH in $\mathrm{D}_{2} \mathrm{O}$, the ${ }^{1} \mathrm{H}$ NMR resonances from $\mathrm{C} 3$ at 2.63 p.p.m. (the aldehyde, 8) and 1.65 p.p.m. (the hydrate, 9) are absent, because the proton that attaches to $\mathrm{C} 3$ in initial enolate formation is now a deuterium, plus, the enolate hydrogen is replaced by a deuterium as well (Fig. 5b). These observations are confirmed by electrospray ionisation mass spectrometry (ESI-MS) (Supplementary Fig. S1) with the results showing formation of an $\mathrm{m} / \mathrm{e}=246.9 \mathrm{amu}$ parent ion, due to water addition to 5 . The hydratase activity of IspH with 5 is $2.0 \mathrm{nmol} \mathrm{min}^{-1} \mathrm{mg}^{-1}$, lower than that of the tungsten iron-sulphur acetylene hydratase $\left(69 \mu \mathrm{mol} \mathrm{min}^{-1} \mathrm{mg}^{-1}\right)^{23}$.

Crystallographic analysis of the IspH:aldehyde (8) complex. Structure elucidation of IspH complexed with the aldehyde $\mathbf{8}$ (prepared by chemical synthesis) at $1.8 \AA$ resolution reveals two ligand conformations: an enolate complex with the apical iron of the $\left[\mathrm{Fe}_{4} \mathrm{~S}_{4}\right]$ cofactor, and a cyclic conformation of the aldehyde in which its oxygen is able to interact with $\mathrm{E} 126 \mathrm{O}^{\varepsilon} \mathrm{H}$ and the ligand's diphosphate group (Fig. 6a). These X-ray structures are consistent with the Mößbauer results, which show that the isomer shift and quadrupole 

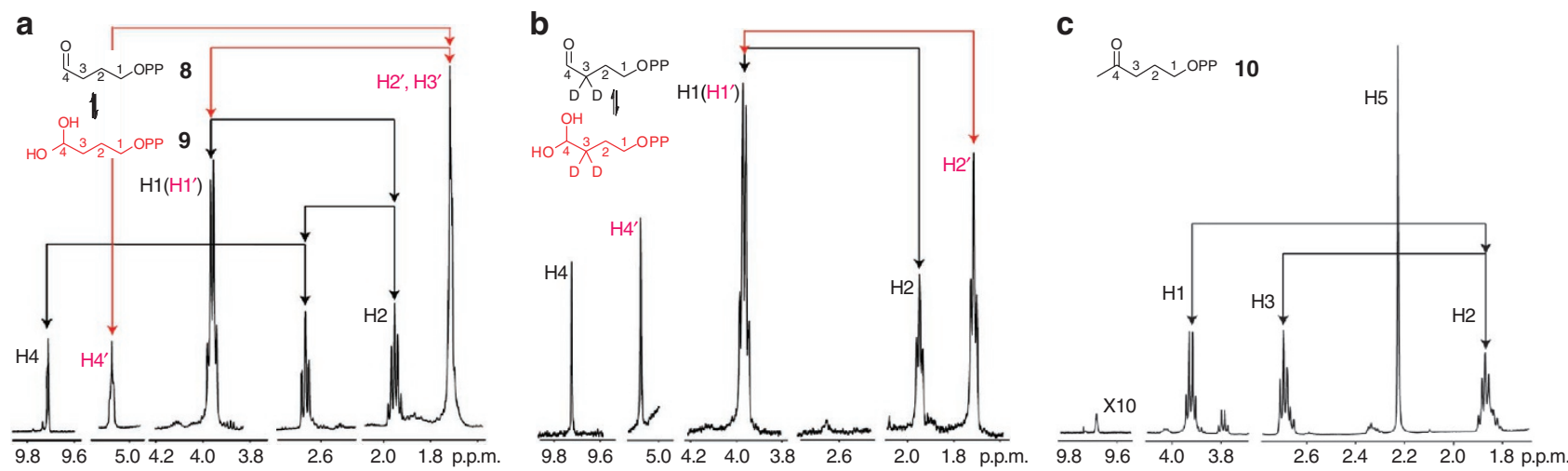

Figure $\mathbf{5}$ | NMR spectroscopic characterization of the IspH hydration products. (a) ${ }^{1} \mathrm{H}$ NMR spectrum $(500 \mathrm{MHz}$ ) of aldehyde 8 (black) and gem-diol $\mathbf{9}$ (red) formed on hydration of $\mathbf{5}$ by IspH. (b) ${ }^{1} \mathrm{H} \mathrm{NMR}$ spectrum $(500 \mathrm{MHz})$ showing the products of hydration of $\mathbf{5}$ by IspH carried out in $\mathrm{D}_{2} \mathrm{O}$, forming $\left[3,3-\mathrm{D}_{2}\right]$ and $\left[3,3-\mathrm{D}_{2}\right]$ 9. (c) ${ }^{1} \mathrm{H}$ NMR spectrum $(500 \mathrm{MHz})$ of the Markovnikov-product 10.
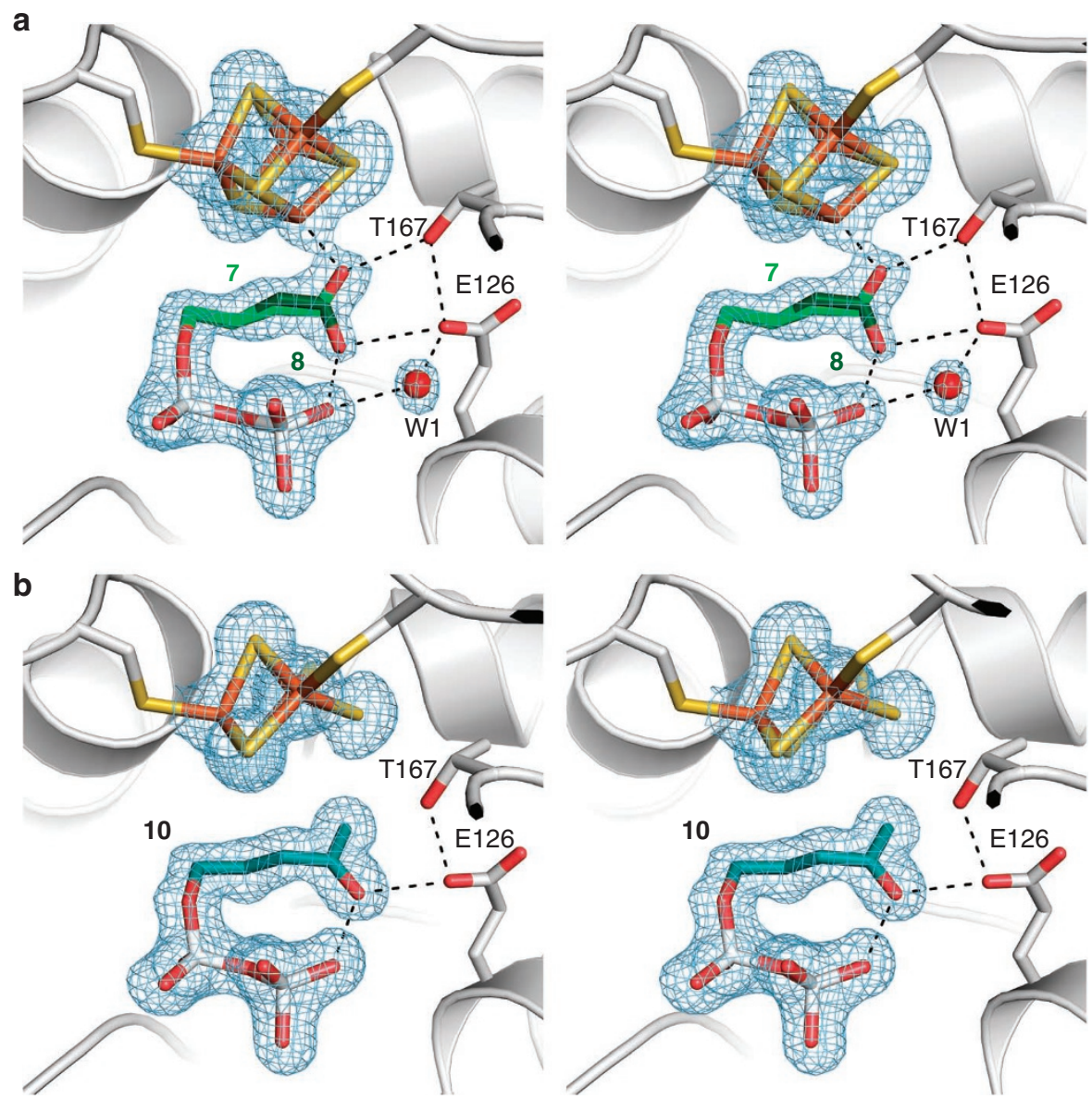

Figure 6 | Stereo presentation of the central cavity of IspH in complex with ligands 8 and 10. Ligands, cofactors, side chains of E126 as well as T167 are displayed according to Fig. 4. A $2 \mathrm{~F}_{\mathrm{O}}-\mathrm{F}_{\mathrm{C}}$ omit electron density map (blue mesh, contoured at $1.4 \sigma$ ) is shown for the $\left[\mathrm{Fe}_{4} \mathrm{~S}_{4}\right]$ cluster, the ligand, and the solvent molecules; dotted lines indicate coordination and hydrogen bonds. (a) 4-Oxobutyl diphosphate (8) bound to the IspH active site shows two alternative orientations: a cyclic conformation of the $\eta^{1}$-O-enolate $\mathbf{7}$ interacting with the fourth iron, and the aldehyde $\mathbf{8}$. The distinct alternative conformations are indicated by the different colours of the carbon atoms. An additional water molecule is located in the W1 position. (b) Structure of $\mathrm{IspH}$ in complex with 4-oxopentyl diphosphate (10) displaying an $\left[\mathrm{Fe}_{3} \mathrm{~S}_{4}\right]$ cluster. The oxidised IspH catalyzes the Markovnikov addition of a water molecule to pent-4-ynyl diphosphate (6), furnishing $\mathbf{1 0 .}$

splitting of the fourth iron decrease on ligand binding, as the enolate provides a $3 \mathrm{~S}, 1 \mathrm{O}$ coordination sphere.

IspH converts pent-4-ynyl diphosphate (6) to a ketone. In the case of $\mathbf{6}$, the Mößbauer results again indicate a 3S,10 coordina- tion to the apical iron of the $\left[\mathrm{Fe}_{4} \mathrm{~S}_{4}\right]$ cluster. The crystal structure determined at $1.8 \AA$ resolution (Fig. 6b) shows a chemically converted compound inside the IspH active site. However, rather than forming an aldehyde (via anti-Markovnikov addition), the nuclear magnetic resonance (NMR) results (Fig. 5c) indicate primarily 
a
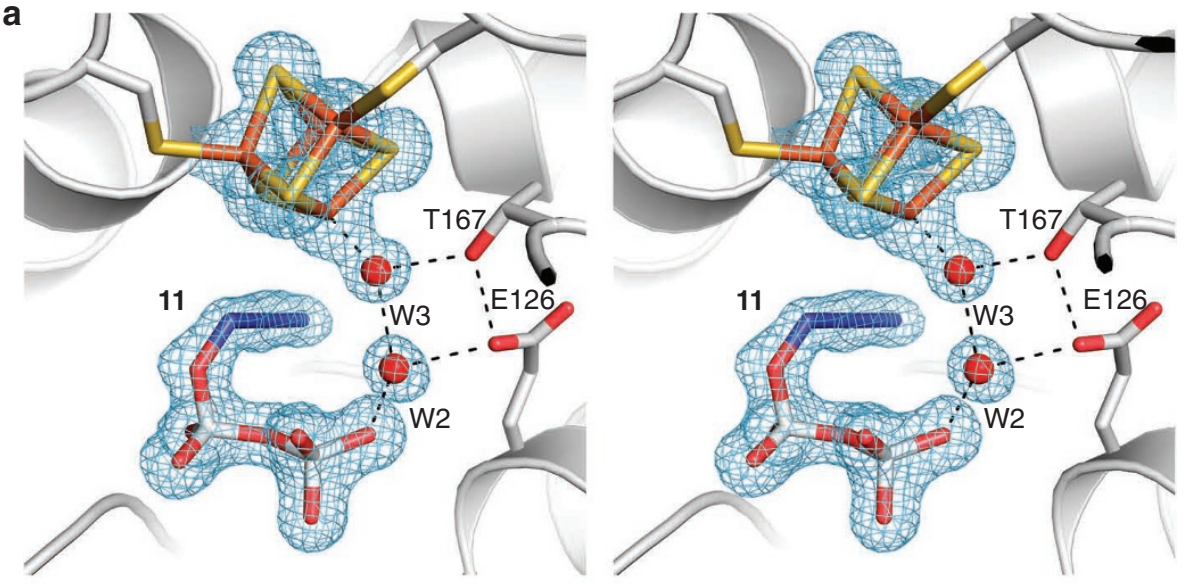

b
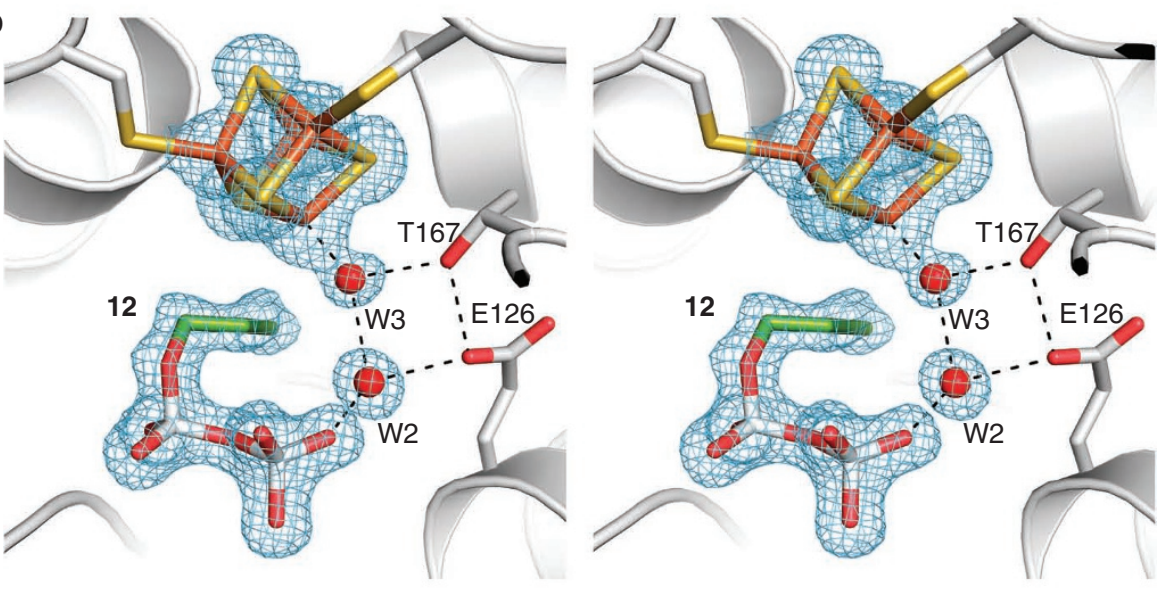

C
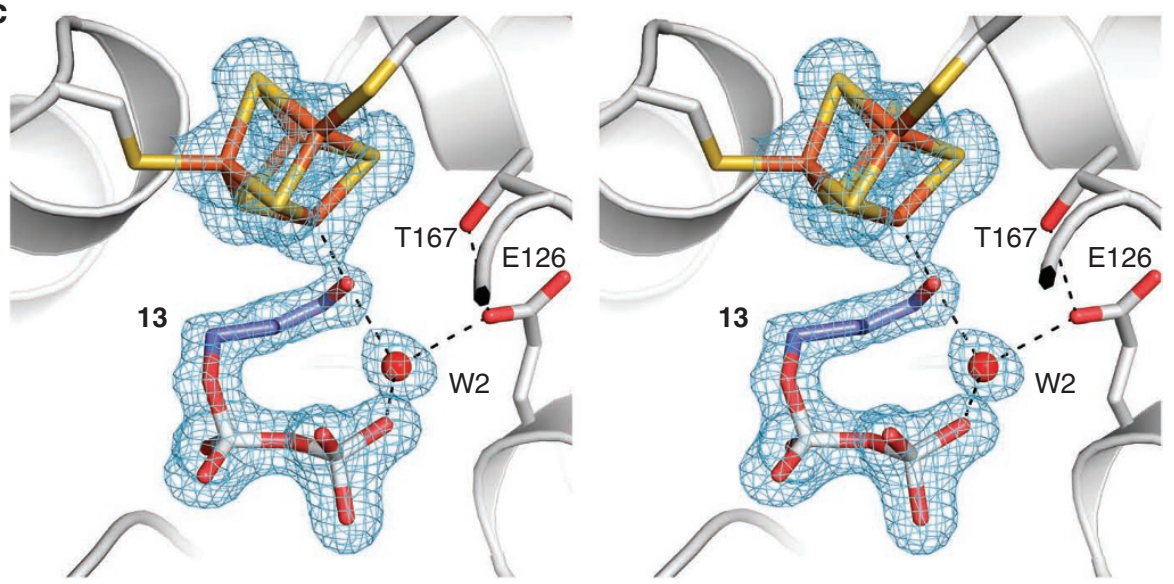

Figure 7 | Stereo presentation of the active site of IspH in complex with ligands 11, 12 and 13. Protein, cofactors, ligands and solvent molecules are represented according to Fig. 4 . A $2 F_{O}-F_{C}$ omit electron density map (blue mesh, $1.4 \sigma$ ) is shown for the cofactors, the ligands, as well as the water molecules. (a) The IspH:but-2-ynyl diphosphate (11) complex structure displays a $\left[\mathrm{Fe}_{4} \mathrm{~S}_{4}\right]$ cluster and an unreacted ligand with two solvent molecules in positions W2 and W3. The alkyne group of $\mathbf{1 1}$ is shifted compared with $\mathbf{5}$, thus there is no interaction with the iron and the carbon chain is rotated towards a hydrophobic pocket formed by A73 and H74. (b) Buta-2,3-dienyl diphosphate (12) adopts a similar orientation and the solvent molecules are located in identical positions as those observed in the structure of IspH bound to 11. (c) Binding of 4-hydroxybutyl diphosphate (13) to IspH results in formation of an $\eta^{1}$-alkoxide (or possibly, an alcohol) complex with the apical iron of the $\left[\mathrm{Fe}_{4} \mathrm{~S}_{4}\right]$ cluster. In addition, one water molecule is evident in the W2 site.

the formation of 4-oxopentyl diphosphate (10) via Markovnikov addition, confirming the results of MS (Supplementary Fig. S1). The Mößbauer spectra suggest initial enolate formation as observed with $\mathbf{5}$, but surprisingly, the X-ray structure of the complex (Fig. 6b) contains a $\left[\mathrm{Fe}_{3} \mathrm{~S}_{4}\right]$ cluster, so evidently the fourth iron is lost during crystallization. The structure of the ketone $\mathbf{1 0}$ is, nevertheless, superimposable with that of the enolate 7 (Supplementary Fig. S2, root-mean-square deviation $(\mathrm{rmsd})=0.350 \AA$ ). The hydratase activity of IspH using 6 as the substrate is $10 \mathrm{nmol} \mathrm{min}{ }^{-1} \mathrm{mg}^{-1}$, five times higher than that found with 5.

X-ray studies of diphosphates with various functional groups. Finally, we investigated the bonding of three additional ligands: 11-13. The methyl-substituted analogue of 4 but-2-ynyl diphosphate 
a
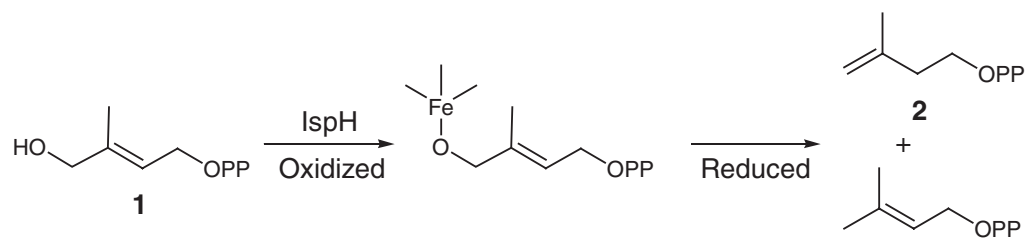

b

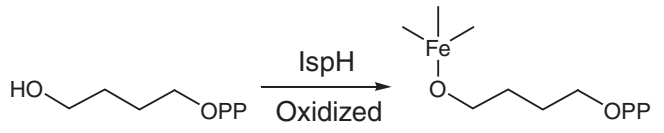

3

13

C

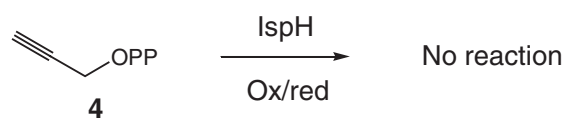

d
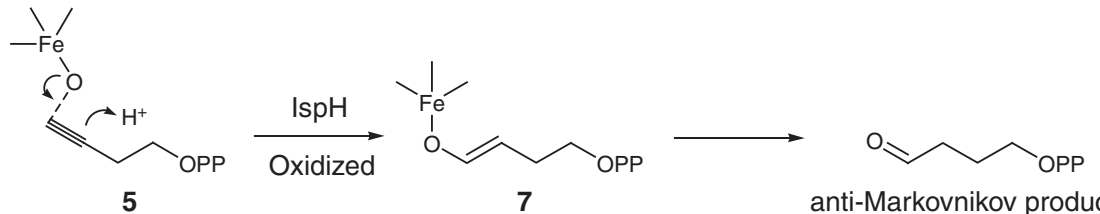

e
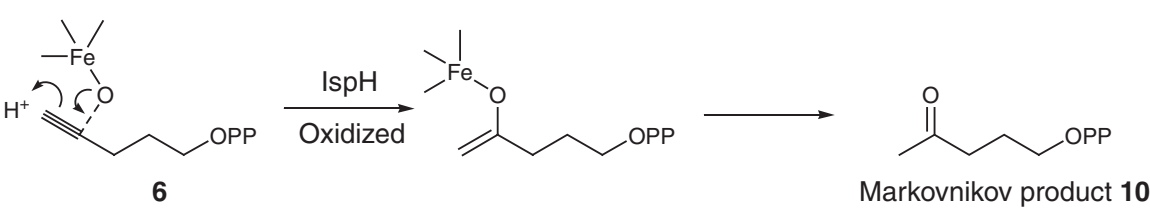

Figure $\mathbf{8}$ | Schematic presentation of the diverse reactions catalysed by the $\left[\mathrm{Fe}_{\mathbf{4}} \mathbf{S}_{\mathbf{4}}\right]$ cluster-containing protein IspH. (a) The unsaturated alcohol $\mathbf{1}$ [(E)-4-hydroxy-3-methylbut-2-enyl diphosphate] binds to the cluster and is reductively dehydroxylated to isopentenyl diphosphate (2) and dimethylallyl diphosphate (3). (b) The $\mathrm{C}_{4}$ alcohol $\mathbf{1 3}$ binds to oxidised IspH but does not react further. (c) The $\mathrm{C}_{3}$ alkyne $\mathbf{4}$ is not converted by oxidised or reduced IspH. (d) The $\mathrm{C}_{4}$ alkyne $\mathbf{5}$ is hydrated at $\mathrm{C} 4$ in anti-Markovnikov fashion forming an $\eta^{1}$-enolate bound to the apical iron of the $\left[\mathrm{Fe}_{4} \mathrm{~S}_{4}\right]$ cluster, resulting in the aldehyde 8. (e) The $\mathrm{C}_{5}$ alkyne $\mathbf{6}$ reacts with oxidised IspH at $\mathrm{C} 4$, this time to form the ketone $\mathbf{1 0}$ in a Markovnikov addition. Notably, all reactions involve interactions of the apical iron in the cluster with the oxygen bound to $\mathrm{C} 4$ of the ligands.

(11, Fig. 7a) as well as buta-2,3-dienyl diphosphate (12, Fig. 7b) both bind in the active pocket of $\mathrm{IspH}$, although no interaction with the iron-sulphur cluster and no chemical reactions were observed. Interestingly, 4-hydroxybutyl diphosphate (13) also binds to the oxidised iron-sulphur cluster via $\mathrm{O} 4$ with an $\mathrm{Fe}-\mathrm{O}$ bond length of $2.1 \AA$ (Fig. 7c), and adopts a similar conformation to that observed in the alkoxide complex formed by IspH in the presence of 1 (Supplementary Fig. S3). ${ }^{21}$ However, 13 did not react further with IspH.

\section{Discussion}

The results presented above all indicate that the $2 \mathrm{H}^{+} / 2 \mathrm{e}^{-}$reductase IspH, which physiologically catalyses the reductive dehydroxylation of HMBPP to form isopentenyl diphosphate and dimethylallyl diphosphate, is promiscuous. The root cause of this promiscuity involves the addition or removal of $\mathrm{OH}$ groups at $\mathrm{C} 4$ in bound ligands (Fig. 8). The substrate HMBPP (1) forms a complex with the fourth $\mathrm{Fe}$ via $\mathrm{O} 4$ and under reducing conditions dehydroxylation ensues (Fig. 8a). The alcohol 13 binds to the apical iron via the 4$\mathrm{OH}$ as an alkoxide (or alcohol; Fig. 8b), but contrary to the situation found with aconitase, no dehydration occurs. The $\mathrm{C}_{3}$ side chain of the acetylene 4 is too short to interact directly with the oxidised cluster (Fig. $8 \mathrm{c}$ ), but with the $\mathrm{C}_{4}$ species 5 , a hydroxide (presumably from a cluster-bound water molecule) adds to $\mathrm{C} 4$ via anti-Markovnikov addition to form the $\eta^{1}$-O-enolate 7 , which is subsequently released as the aldehyde $\mathbf{8}$ (Fig. $8 \mathrm{~d}$ ). With a $\mathrm{C}_{5}$ side chain in $\mathbf{6}$, oxygen once again adds at C4, but now, protonation must be at C5 (Markovnikov addition) resulting in the formation of ketone $\mathbf{1 0}$ (Fig. 8e). The conversion of these IspH substrates is only catalysed by the oxidised form of IspH, no reaction is observed with the reduced protein. These results thus reveal an unexpected side to IspH reactivity, which can be expected to be of importance in inhibitor design and potentially, in chemical synthesis. In addition, these data support the idea that metal-enolate complexes may be involved in acetylene hydratase activity in other systems, as proposed on theoretical grounds ${ }^{17}$.

\section{Methods}

Synthetic protocols. All reagents utilized were purchased from Aldrich (Milwaukee, WI). The purity of each compound investigated was confirmed by ${ }^{1} \mathrm{H}$ and ${ }^{31} \mathrm{P}$ NMR spectroscopy at $400 \mathrm{MHz}$ or $500 \mathrm{MHz}$ performed on Varian (Palo Alto, CA) Unity spectrometers. Cellulose thin layer chromatography (TLC) plates were visualized by using iodine or a sulphosalicylic acid-ferric chloride stain. The syntheses and characterization of 4-6, 8,9 and 11 were described previously ${ }^{18,22}$.

General procedure for preparation of diphosphates. Diphosphates were prepared using modified literature procedures ${ }^{24}$. Typically, $1 \mathrm{mmol}$ of halide or mesylate in a minimum amount of $\mathrm{CH}_{3} \mathrm{CN}(0.5 \mathrm{ml})$ was added drop-wise to a stirred solution of $2.70 \mathrm{~g}(3.0 \mathrm{mmol})$ tris(tetra- $n$-butylammonium)hydrogen diphosphate in $\mathrm{CH}_{3} \mathrm{CN}(4 \mathrm{ml})$ at $0^{\circ} \mathrm{C}$. The reaction mixture was stirred for $2-24 \mathrm{~h}$ at room temperature and the solvent was removed under reduced pressure. The residue was dissolved in cation-exchange buffer $\left(49: 1(\mathrm{v} / \mathrm{v}) 25 \mathrm{mM} \mathrm{NH}_{4} \mathrm{HCO}_{3} / 2\right.$-propanol) and slowly passed over 60-100 mequiv Dowex AG50W-X8 (100-200 mesh, ammonium form) cation-exchange resin, pre-equilibrated with volumes of the same buffer. The product was eluted with two column volumes of the same buffer, flash frozen, 
and lyophilized. The resulting powder was dissolved in $3 \mathrm{ml}$ of $50 \mathrm{mM} \mathrm{NH}_{4} \mathrm{HCO}_{3}$. Nine millilitre of 2-propanol/ $\mathrm{CH}_{3} \mathrm{CN}(1: 1(\mathrm{v} / \mathrm{v}))$ was added, mixed, centrifuged for $5 \mathrm{~min}$ at 2000 r.p.m., and the supernatant was subsequently decanted. This procedure was repeated three times and the supernatants were combined. After solvent removal and lyophilization, followed by flash chromatography on cellulose, a white solid was obtained.

Synthesis of compounds. 4-Oxobutyl diphosphate $\mathbf{8}$ and its hydrate 9 were prepared as reported previously for the 3-methyl substituted analogue ${ }^{22} .{ }^{1} \mathrm{H}$ NMR $\left(400 \mathrm{MHz}, \mathrm{D}_{2} \mathrm{O}\right): \delta$, 9.70. (s, $\left.1 \mathrm{H}\right), 5.15-5.05(\mathrm{br}, 1 \mathrm{H}), 4.00-3.86(\mathrm{~m}, 4 \mathrm{H}), 2.66(t$, $J=6.4 \mathrm{~Hz}, 2 \mathrm{H}), 1.98-1.88(\mathrm{~m}, 2 \mathrm{H}), 1.75-1.65(\mathrm{~m}, 4 \mathrm{H}) ;{ }^{31} \mathrm{P} \mathrm{NMR}\left(162 \mathrm{MHz}, \mathrm{D}_{2} \mathrm{O}\right)$ $\delta,-4.64,-4.78$ (two sets dd, $J=22 \mathrm{~Hz}$ ) $,-8.65,-8.77$ (two sets dd, $J=22 \mathrm{~Hz}$ ).

Buta-2,3-dienyl diphosphate (12). Buta-2,3-dienyl methane sulphonate $(148 \mathrm{mg}, 1 \mathrm{mmol})$ in $\mathrm{CH}_{3} \mathrm{CN}(0.5 \mathrm{ml})$ was treated with $2.7 \mathrm{~g}(3 \mathrm{mmol})$ tris (tetra- $n$ butylammonium)hydrogen diphosphate in $\mathrm{CH}_{3} \mathrm{CN}(4 \mathrm{ml})$. Flash chromatography on a cellulose column (2:1:1 (v/v/v) 2-propanol $\left./ \mathrm{CH}_{3} \mathrm{CN} / 50 \mathrm{mM} \mathrm{NH} \mathrm{HCO}_{3}\right)$ yielded $84 \mathrm{mg}(30 \%)$ of a white solid. ${ }^{1} \mathrm{H}$ NMR $\left(400 \mathrm{MHz}, \mathrm{D}_{2} \mathrm{O}\right): \delta, 5.26-5.18(\mathrm{~m}$, $1 \mathrm{H}), 4.77-4.72(\mathrm{~m}, 2 \mathrm{H}), 4.32-4.25(\mathrm{~m}, 2 \mathrm{H}) ;{ }^{31} \mathrm{P}$ NMR $\left(162 \mathrm{MHz}, \mathrm{D}_{2} \mathrm{O}\right): \delta,-9.28$ $(\mathrm{d}, J=20.7 \mathrm{~Hz}),-10.04(\mathrm{~d}, J=20.7 \mathrm{~Hz}) .{ }^{13} \mathrm{C}$ NMR $\left(125 \mathrm{MHz}, \mathrm{D}_{2} \mathrm{O}\right): \delta, 209.1,87.7$, 76.6, 64.2; high-resolution mass spectrometry (HRMS, ESI) calcd. for $\mathrm{C}_{4} \mathrm{H}_{9} \mathrm{O}_{7} \mathrm{P}_{2}$ $[\mathrm{M}+\mathrm{H}]^{+}, 230.9824$; found 230.9834

4-Hydroxybutyl diphosphate (13). 4-Chloro-1-butanol (108 mg, $1 \mathrm{mmol})$ in $\mathrm{CH}_{3} \mathrm{CN}(0.5 \mathrm{ml})$ was treated with $2.7 \mathrm{~g}(3 \mathrm{mmol})$ tris (tetra-nbutylammonium)hydrogen diphosphate in $\mathrm{CH}_{3} \mathrm{CN}(4 \mathrm{ml})$. Flash chromatography on a cellulose column (2:1 (v/v) 2-propanol/50 $\left.\mathrm{mM} \mathrm{NH}_{4} \mathrm{HCO}_{3}\right)$ yielded $105 \mathrm{mg}$ (35\%) of a white solid. ${ }^{1} \mathrm{H}$ NMR $\left(400 \mathrm{MHz}, \mathrm{D}_{2} \mathrm{O}\right): \delta, 3.79(\mathrm{dd}, J=12.4,6.0 \mathrm{~Hz}, 2 \mathrm{H})$ $3.47(\mathrm{t}, J=6.0 \mathrm{~Hz}, 2 \mathrm{H}), 1.54-1.43(\mathrm{~m}, 4 \mathrm{H}) ;{ }^{31} \mathrm{P}$ NMR $\left(162 \mathrm{MHz}, \mathrm{D}_{2} \mathrm{O}\right): \delta,-9.46(\mathrm{~d}$, $J=21.0 \mathrm{~Hz}),-9.73(\mathrm{~d}, J=21.0 \mathrm{~Hz}) ;{ }^{13} \mathrm{C}$ NMR $\left(125 \mathrm{MHz}, \mathrm{D}_{2} \mathrm{O}\right): \delta, 66.5,61.6,27.8$, 26.4; HRMS (ESI) calcd. for $\mathrm{C}_{4} \mathrm{H}_{13} \mathrm{O}_{8} \mathrm{P}_{2}[\mathrm{M}+\mathrm{H}]^{+}, 251.0086$; found, 251.0096

Protein purification. E. coli IspH for crystallization was prepared as reported previously ${ }^{9}$. Protein for spectroscopic analysis was obtained according to the protocol described below. BL-21 (DE3) cells overexpressing E. coli IspH (encoded in plasmid pASK-IBA3 ${ }^{+}$) and Isc proteins (encoded in plasmid pDB1282) were grown in Luria-Bertani media supplemented with $100 \mathrm{mgl}^{-1}$ ampicillin and $50 \mathrm{mgl}^{-1}$ kanamycin at $37^{\circ} \mathrm{C}$, until the $\mathrm{OD}_{600}$ reached 0.3 . Cells were then induced with $0.5 \mathrm{gl}^{-1}$ arabinose to initiate overexpression of the Isc proteins. Cysteine $(1 \mathrm{mM})$ and $\mathrm{FeCl}_{3}(0.1 \mathrm{mM})$ were supplemented, and cells were grown until the $\mathrm{OD}_{600}$ reached 0.6. At this point, $400 \mu \mathrm{gl}^{-1}$ anhydro-tetracycline was added to induce overexpression of IspH. Cells were grown at $25^{\circ} \mathrm{C}$ for $16 \mathrm{~h}$, harvested by centrifugation and kept at $-80^{\circ} \mathrm{C}$ until use. All purification steps were carried out in a Coy Vinyl Anaerobic Chamber (Coy Laboratories, Grass Lake, MI) with an oxygen level $<2$ p.p.m., and all buffers were degassed by using a Schlenk line. Cell pellets were re-suspended in $100 \mathrm{mM}$ Tris/ $\mathrm{HCl}, 150 \mathrm{mM} \mathrm{NaCl}$ buffer ( $\mathrm{pH}$ 8.0). Lysozyme, Benzonase nuclease (EMD Chemicals, San Diego, CA) and phenylmethanesulfonyl fluoride were added, and the mixture was stirred for $1 \mathrm{~h}$ at $10^{\circ} \mathrm{C}$ followed by sonication (Fisher Scientific Sonic Dismembrator, Model 500) with four pulses, each $7 \mathrm{~s}$ duration, at $35 \%$ power. The cell lysate was centrifuged at 11,000 r.p.m. at $10^{\circ} \mathrm{C}$ for $30 \mathrm{~min}$. The supernatant was purified by using Strep-tactin chromatography ${ }^{25}$ Fractions having a brown colour were collected and desalted in $\mathrm{pH} 8.0$ buffer containing $100 \mathrm{mM} \mathrm{Tris} / \mathrm{HCl}$ and $150 \mathrm{mM} \mathrm{NaCl} .{ }^{57} \mathrm{Fe}$-enriched IspH was prepared following the same procedures as for natural-abundance IspH, described above, except that ${ }^{57} \mathrm{Fe}$ metal dissolved in $\mathrm{HCl}$ was added to the Luria-Bertani media to a final concentration of $80 \mu \mathrm{M}$.

Spectroscopy. Mößbauer spectra were recorded on a constant acceleration spectrometer (Knox College) at $77 \mathrm{~K}$ with a $500 \mathrm{G}$ magnetic field perpendicular to the $\gamma$-ray. NMR spectra were collected on a $500 \mathrm{MHz}$ Varian Unity spectrometer and ESI-MS spectroscopy was performed on a Waters Quattro II mass spectrometer.

Crystallization. Co-crystallization of IspH and the inhibitors was performed under anaerobic conditions in a Coy Vinyl Anaerobic Chamber (Coy Laboratories, Grass Lake, MI) with an $\mathrm{N}_{2} / \mathrm{H}_{2}(95 \% / 5 \%)$ atmosphere. All buffers were refluxed for $20 \mathrm{~min}$ and were stored under argon. A $100 \mathrm{mM}$ aqueous solution of each inhibitor was prepared with degassed water and stored under anaerobic conditions at $-80^{\circ} \mathrm{C}$. A protein solution with a concentration of $18.3 \mathrm{mg} \mathrm{ml}^{-1}$ was incubated with $1 \mathrm{mM}$ inhibitor before crystallization. Dark brown crystals were obtained by using the sitting drop vapour diffusion method at $20^{\circ} \mathrm{C}$ with $100 \mathrm{mM}$ BisTris $/ \mathrm{HCl}$, $\mathrm{pH} 6.5,200 \mathrm{mM}$ ammonium sulphate and $25 \%$ polyethylene glycol 3350 as precipitant. Crystals were soaked with cryo-protectant solution (50\% aqueous polyethylene glycol 400) for $1 \mathrm{~min}$, mounted on loops and flash cooled in a stream of nitrogen gas at $100 \mathrm{~K}$ (Oxford Cryo Systems).

Data collection and structure determination. Native data sets were collected at $1.0 \AA$ and $100 \mathrm{~K}$ using synchrotron radiation at the X06SA-beamline at the Swiss Light Source, Villigen, Switzerland and at the ID29-beamline at the European Synchrotron Radiation Facility, Grenoble, France. The phase problem was solved by molecular replacement using the coordinates of $E$. coli IspH bound to the substrate HMBPP (PDB ${ }^{26}$ ID: 3KE8) as the starting model ${ }^{9}$. Data were processed using the program package $\mathrm{XDS}^{27}$. The anisotropy of diffraction was corrected using TLS refinement ${ }^{28}$. Model building and refinement were performed with $\operatorname{Coot}^{29}$ and Refmac $^{30}$. Figures were prepared using $\mathrm{PyMOL}^{31}$ and Ramachandran plots were calculated with PROCHECK ${ }^{32}$. Ramachandran statistics for the refined structures are 98.7/1.3/0.0 (Crystal 1 IspH:4), 98.8/1.2/0.0 (Crystal 2 IspH:7), 98.4/1.6/0.0 (Crystal 3 IspH:8), 99.0/1.0/0.0 (Crystal 4 IspH:10), 99.0/1.0/0.0 (Crystal 5 IspH:11), 98.9/1.1/0.0 (Crystal 6 IspH:12) and 99.0/1.0/0.0 (Crystal 7 IspH:13). For more details see Supplementary tables S1 and S2.

\section{References}

1. Beinert, H., Holm, R. H. \& Munck, E. Iron-sulfur clusters: nature's modular, multipurpose structures. Science 277, 653-659 (1997).

2. Seino, H. \& Hidai, M. Catalytic functions of cubane-type $\mathrm{M}_{4} \mathrm{~S}_{4}$ clusters. Chem. Sci. 2, 847-857 (2011).

3. Beinert, H., Kennedy, M. C. \& Stout, C. D. Aconitase as iron-sulfur protein, enzyme, and iron-regulatory protein. Chem. Rev. 96, 2335-2374 (1996).

4. Cammack, R. Iron-sulfur clusters in enzymes - themes and variations. $A d v$. Inorg. Chem. Rad. 38, 281-322 (1992).

5. Wolff, M. et al. Isoprenoid biosynthesis via the methylerythritol phosphate pathway: the (E)-4-hydroxy-3-methylbut-2-enyl diphosphate reductase (LytB/ $\mathrm{IspH}$ ) from Escherichia coli is a [4Fe-4S] protein. FEBS Lett. 541, 115-120 (2003)

6. Altincicek, B. et al. LytB protein catalyzes the terminal step of the 2-C-methylD-erythritol-4-phosphate pathway of isoprenoid biosynthesis. FEBS Lett. 532, 437-440 (2002).

7. Rohdich, F. et al. The deoxyxylulose phosphate pathway of isoprenoid biosynthesis: studies on the mechanisms of the reactions catalysed by IspG and IspH protein. Proc. Natl Acad. Sci. USA 100, 1586-1591 (2003).

8. Rekittke, I. et al. Structure of (E)-4-hydroxy-3-methyl-but-2-enyl diphosphate reductase, the terminal enzyme of the non-mevalonate pathway. J. Am. Chem. Soc. 130, 17206-17207 (2008).

9. Gräwert, T. et al. Structure of active IspH enzyme from Escherichia coli provides mechanistic insights into substrate reduction. Angew. Chem. Int. Ed. 48, 5756-5759 (2009).

10. Span, I., Gräwert, T., Bacher, A., Eisenreich, W. \& Groll, M. Crystal structures of mutant IspH proteins reveal a rotation of the substrate's hydroxymethyl group during catalysis. J. Mol. Biol. 416, 1-9 (2012).

11. Gräwert, T., Span, I., Bacher, A. \& Groll, M. Reductive dehydroxylation of allyl alcohols by IspH protein. Angew. Chem. Int. Ed. 49, 8802-8809 (2010).

12. Citron, C. A, Brock, N. L., Rabe, P. \& Dickschat, J. S. The stereochemical course and mechanism of the IspH reaction. Angew. Chem. Int. Ed. 51, 4053-4057 (2012)

13. Rohmer, M., Grosdemange-Billiard, C., Seemann, M. \& Tritsch, D. Isoprenoid biosynthesis as a novel target for antibacterial and antiparasitic drugs. Curr. Opin. Investig. Drugs 5, 154-162 (2004).

14. Hunter, W. N. Isoprenoid precursor biosynthesis offers potential targets for drug discovery against diseases caused by apicomplexan parasites. Curr. Top. Med. Chem. 11, 2048-2059 (2011).

15. Obiol-Pardo, C., Rubio-Martinez, J. \& Imperial, S. The methylerythritol phosphate (MEP) pathway for isoprenoid biosynthesis as a target for the development of new drugs against tuberculosis. Curr. Med. Chem. 18, 1325-1338 (2011).

16. Seiffert, G. B. et al. Structure of the non-redox-active tungsten/[4Fe:4S] enzyme acetylene hydratase. Proc. Natl Acad. Sci. USA 104, 3073-3077 (2007).

17. Liao, R. Z., Yu, J. G. \& Himo, F. Mechanism of tungsten-dependent acetylene hydratase from quantum chemical calculations. Proc. Natl Acad. Sci. USA 107, 22523-22527 (2010).

18. Wang, K., Wang, W., No, J. H., Zhang, Y. \& Oldfield, E. Inhibition of the $\mathrm{Fe}_{4} \mathrm{~S}_{4}{ }^{-}$ cluster-containing protein IspH (LytB): electron paramagnetic resonance, metallacycles, and mechanisms. J. Am. Chem. Soc. 132, 6719-6727 (2010).

19. Seemann, M. et al. Isoprenoid biosynthesis via the MEP pathway: in vivo Mössbauer spectroscopy identifies a $[4 \mathrm{Fe}-4 \mathrm{~S}]^{2+}$ center with unusual coordination sphere in the LytB protein. J. Am. Chem. Soc. 131, 13184-13185 (2009).

20. Ciurli, S. et al. Subsite-differentiated analogs of native $[4 \mathrm{Fe}-4 \mathrm{~S}]^{2+}$ clusters preparation of clusters with 5-coordinate and 6-coordinate subsites and modulation of redox potentials and charge-distributions. J. Am. Chem. Soc. 112, 2654-2664 (1990).

21. Gräwert, T. et al. Probing the reaction mechanism of IspH protein by x-ray structure analysis. Proc. Natl Acad. Sci. USA 107, 1077-1081 (2010).

22. Zhang, Y. et al. Structural studies of V $\gamma 2 \mathrm{~V} \delta 2 \mathrm{~T}$ cell phosphoantigens. Chem Biol. 13, 985-992 (2006).

23. Rosner, B. M. \& Schink, B. Purification and characterization of acetylene hydratase of Pelobacter acetylenicus, a tungsten iron-sulfur protein. J. Bacteriol. 177, 5767-5772 (1995).

24. Davisson, V. J. et al. Phosphorylation of isoprenoid alcohols. J. Org. Chem. 51, 4768-4779 (1986).

25. Schmidt, T. G. M. \& Skerra, A. The Strep-tag system for one-step purification and high-affinity detection or capturing of proteins. Nat. Protoc. 2, 1528-1535 (2007). 
26. Bernstein, F. C. et al. The Protein Data Bank. A computer-based archival file for macromolecular structures. Eur. J. Biochem. 80, 319-324 (1977).

27. Kabsch, W. Automatic processing of rotation diffraction data from crystals of initially unknown symmetry and cell constants. J. Appl. Cryst. 26, 795-800 (1993).

28. Brünger, A. T. et al. Crystallography \& NMR system: a new software suite for macromolecular structure determination. Acta Crystallogr. D Biol. Crystallogr. 54, 905-921 (1998).

29. Emsley, P. \& Cowtan, K. Coot: model-building tools for molecular graphics. Acta Crystallogr. D Biol. Crystallogr. 60, 2126-2132 (2004).

30. Murshudov, G. N., Vagin, A. A. \& Dodson, E. J. Refinement of macromolecular structures by the maximum-likelihood method. Acta Crystallogr. D Biol. Crystallogr. 53, 240-255 (1997).

31. The PyMOL Molecular Graphics System, V. r. p., Schrödinger, LLC.

32. Laskowski, R. A., Rullmannn, J. A., MacArthur, M. W., Kaptein, R. \& Thornton, J. M. AQUA and PROCHECK-NMR: programs for checking the quality of protein structures solved by NMR. J. Biomol. NMR 8, 477-486 (1996).

\section{Acknowledgements}

We thank Drs Lukas Hintermann, Jörg Eppinger and Tobias Gräwert, TUM, for their valuable feedback. The staffs of the X06SA-beamline at the Paul Scherer Institute, Swiss Light Source, Villigen, Switzerland and of the ID29-beamline at the European Synchrotron Radiation Facility, Grenoble, France are acknowledged for help during data collection. This work was supported by TUM Graduate School, Hans-Fischer
Gesellschaft, DFG grant GR1861/5-1, NIH grants GM65307 and AI074233, and American Heart Association Predoctoral Fellowship 10PRE4430022.

\section{Author contributions}

E.O. and M.G. designed and supervised the project, W.E. and A.B. initiated the project W.W. and I.S. expressed and purified the protein, I.S. performed crystallization, data collection, processing and refinement, K.W., Y.Z. and K.L. synthesized compounds, W.W performed NMR/ESI-MS study of the reaction, W.W. and C.S. collected Mößbauer data, E.O. and M.G. wrote the manuscript.

\section{Additional information}

Accession codes: Coordinates and structure factors for IspH in complex with the ligands $4,7,8,10,11,12$ and 13 have been deposited in the Protein Data Bank under accession codes 3URK, 3UTC, 3UWM, 3UTD, 3UV3, 3UV7 and 3UV6, respectively.

Supplementary Information accompanies this paper at http://www.nature.com/ naturecommunications

Competing financial interests: The authors declare no competing financial interests.

Reprints and permission information is available online at http://npg.nature.com/ reprintsandpermissions/

How to cite this article: Span, I. et al. Discovery of acetylene hydratase activity of the iron-sulphur protein IspH. Nat. Commun. 3:1042 doi: 10.1038/ncomms2052 (2012). 